\title{
The Impact of Modern Technology on Providing Counseling Services in the Light of Some Variables
}

\author{
Nashat Abu Hassouneh ${ }^{1} \&$ Asad Farhan Alzoubi ${ }^{2}$ \\ ${ }^{1}$ Dean Faculty of educational studies, Irbid National University, Jordan \\ ${ }^{2}$ Physiological Counseling Department, University of Jordan, Jordan \\ Correspondence: Nashat Abu Hassouneh, Dean Faculty of educational studies, Irbid National University, Jordan. \\ E-mail: nabuhassouneh@yahoo.com
}

\author{
Received: January 9, 2019 Accepted: February 2, 2019 Online Published: February 25, 2019 \\ doi:10.5539/jel.v8n2p132 URL: https://doi.org/10.5539/jel.v8n2p132
}

\begin{abstract}
This study analyses the impact of modern technology on the provision of consulting services in the light of some variables. The study sample consisted of 125 counselors. The results showed that the sample of the study had average level of using modern technology as a tool, and the absence of statistically significant differences depending on the following variables: gender, the qualification on the study tool, while the existence of a statistically significant differences in the following variables: age for those whom under than 45 years, and years of experiences for the less than 5 years. In addition, the study showed statistically significance effect in modern technology on the provision of counseling services and its infrastructure.
\end{abstract}

Keywords: modern technology, counseling services

\section{Introduction}

The proliferation of the digital technology has become increasingly dominant in human life in the 21 st century, therefore the provision of counseling services will become essential to receive services, but the service providers need a period of transition to overcome their fears of using technology, and eliminating their loyalty to the familiar and traditional ways in addition to adopting the new changes so that we can provide services to the guides in a more effective, easy and available way and lowest costs.

The digital revolution and social media are powerful incentive for remote counseling services, because people are resorting to the use of technology in various fields, the so-called digital population, where the provision of remote counseling service is based on the operative word and visual observation (Zur, 2012).

We all live in this life with problems that make us need for counseling services to overcome them, so the process of guidance has evolved, and became an educational and social necessity, not scientific luxury. All of us in this life need these counseling services regardless the age because of the social and economic, professional and technical changes, whether in schools, universities, families or various institutions of the community (Takroni, 2012).

Counseling services are valuable in the human life because they contribute significantly to support them psychologically, socially and educationally, such as offering counseling services in the religious, moral, psychological, social, educational, and vocational field (Al Harthy, 2015). The counselor in the school is a key element because of his important role in supporting the student and address personal and social needs (Ratliff, Ebbs, \& Isom, 2012).

Technology can be a useful tool in the counseling work by: (1) Communicate with parents of the students by creating an electronic newsletter, audio files, web pages and presentations on school counseling topics. (2) Giving students counseling courses and programs via the internet. (3) University and exploration programs such as Naviance. (4) Language translation programs to help overcome language barriers. (5) The web site activities are in the directory of individuals, groups and classes. (6) Social applications for training in social skills (Ratliff et al., 2012).

Remote counseling services include:

1) Intervention in crisis situation through contact with service recipients within the counseling session. 
2) Conducting sessions with individuals who are unable to attend the counseling session because of the healthy or physical or psychological problems or lack of transportation.

3) Provide services related to case evaluation, counseling, provision, protection, and treatment of mental disorders.

4) Conduct psychotherapy over the phone or the internet at the same time or via video conference, virtual reality, text messages, email or chat (Zur, 2012).

Remote counseling services fill the gap by providing services for:

1) Those that cannot easily get care in their communities.

2) Who live in rural and remote areas?

3) Who are unable to reach the service offices?

4) for non-traditional service providers.

5) To complete online skills training.

6) To save time in order to face multiple challenges.

7) To focus on providing services that requires their expertise.

8) To enable them to review content frequently as psychological educational materials without the need to devote intensive time for these activities (Bickle, Marsch, \& Budney, 2013).

9) To help service providers work with largest number of individuals or by for longer periods of time by providing online services.

10) Allow who need guidance to get services when they need.

11) To get flexible time by integrating technologies that enable asynchronous communication that makes services available on demand in a timely manner.

12) To create new forms of intervention and reduce barriers in order to get care (Campbell et al., 2014).

13) To be able to integrate new information easily and export quickly.

14) To be able to integrate updates into the content of the program and make it available to all users at the same time.

15) To get the latest scientific developments quickly and continuously.

16) Enable individuals to control and monitor their care and recovery.

17) To keep up with the latest research and train new service providers.

18) To increase the effectiveness of evaluation tools and technology-based on intervention in term of cost (Aronson, Plass, \& Bania, 2012).

Technology-based services may be self-directed with specific sub-groups of guides such as:

1) Self-directed service:

These services are based on technology by offering stand-alone programs through websites, where the individuals can use them without the help of a service provider, in addition to how to use the program in the right way.

\section{2) Web-based services:}

Includes therapeutic tools over the internet such as interactive training program, interactive training online and web-based behavior management program that allow: (1) Provides the ability to update and publish content within a program in order to obtain the information easily. (2) Follow up the activity of individuals within the program through the login information. (3) Collecting individuals' data into groups so that service providers can review information for all.

\section{3) Services on site:}

This service is done by having a copy on the web. It provides the following services: (1) provide individuals with the appropriate solution to the situation. (2) Evaluate the counseling provided effectively. (3) Education and training are essential adaptive skills by providing examples based on video. (4) It provides the individuals to gain new skills (Mheu, McMenamin, \& Pulier, 2013). 
The advantages of using e-academic counseling can be summarized as follows: (1) Communication between the counselor and the person who need the guidance through the website. (2) Freedom from the constraints of time and place. (3) To know the news of counselor and the individual periodically. (4) The existence of clear information about individuals through the electronic information available on the site. (5) Elimination of psychological barrier between the guide and individuals. (6) Ease of communication between the counselor and individuals to exchange information and conduct incentive initiatives. (7) The mutual benefit between the guide and the individuals through the information available on the websites (Al-Qwasami, 2017).

The advantages of the counseling sites are: (1) Ease of installing the system and dealing with its vocabulary. (2) Providing an interactive environment and different tasks for the beneficiary person. (3) The ability to develop adaptive knowledge and modern technical requirements. (4) It contains activities that supporting the counseling process such as: forums, resources and instruction. (5) The ability of the system to deal with a wide range of electronic and multimedia tools. (6) Easy to download files and link it with the helping software that works on the internet. (7) Provides ready educational and cognitive forms for use. (8) Provide programs for displaying electronic counseling models (Al-Qwasami, 2017).

Service providers are currently showing resistance, and are slowly showing into adapting services through modern technology, so resistance is represented in five factors are: (1) Cyberbullying. (2) Online confidentially. (3) Internet threats. (4) Pornographic material and non-ethical online. (5) The safety of using internet (Ratliff et al., 2012). However there are some objections:

1) The service providers are specialists in the psychological field and not in the field of technological, so their focus is on the psychological rather than the technological.

2) Service providers are professionals of the old generation, but who either individuals entered the field, are digital individuals and feel comfortable with using technology.

3) Although service providers are highly adapted, they reject technology as inappropriate.

4) The means of technology used to provide services are based on non-communication face to face and this is contrary of language body skills (Zur, 2012).

The challenges facing the counseling services in the digital world:

1) Confidentiality and privacy: anxiety of unauthorized access to digital data for computer and video conferencing.

2) Some counseling providers are not licensed, and there is no jurisdiction to prosecute them.

3) Fears of using technology: such as safety, confidentiality, and non-protection of these programs.

4) Scope of practice: service providers must be highly efficient.

5) Determine the person who needs guidance: concern about age, nationality, identity, ability to approve treatment and gender.

6) Prior approval: the service providers shall take the prior approval of the beneficiary after clarifying the risks.

7) Record keeping: keeps records, videoconferences, text or face-to-face meetings, all these are stored on a computer or account storage.

8) Local emergency sources: attention should be paid to medical and psychological emergencies due to different geographical areas (Zur \& Zur, 2016). Services providers should know how to use technology appropriately since there are situations where technology cannot be used, such as domestic violence and suicide (Maheu et al., 2013).

Problems of the study

The researcher noted through his job as counselor and lecturer the lack of using modern technology in providing counseling services, in addition that the old counselor finds it difficult to deal with modern technology so they avoid using it and they believe that it must be face to face during the educational process. Therefore, the researcher finds that communication skills through modern technology must be developed by the counselor. In addition to the lack of Arab studies in this field. The researcher believes that this study one of the first studies that dealt with the impact of modern technology on the provision of counseling services at the local and Arab level. So, this study came in order to answer the following questions:

1) Does technology contribute to providing counseling services? 
2) Are there differences of statistical significance for modern technology according to: gender, age, educational qualification and years of experiences?

3 ) Is there a statistically significant relation at the level $(\alpha \leq 0.05)$ for the impact of modern technology on the provision of counseling services?

4) Is there a statistically significant relation at the level $(\alpha \leq 0.05)$ for the impact of the infrastructure modern technology on the provision of counseling services?

\section{Importance of the study}

The theoretical important of the study is to shed the light on modern technology including various social network programs, and the prevalence of the use of social media among beneficiaries from counseling services. The results of the study are expected to help educators, teachers and faculty members at universities to include their lessons communication skills via modern technology.

In terms of the applied framework, the study provides the counselor by the importance of modern communication methods in providing remote counseling services for people who are unable to personally attend the location of service. In addition, the result of the study will contribute to open way for the researchers to conduct studies on this topic.

Aims of the study

This study aims to examine the impact of modern technology on providing counseling services in the light of some variables.

\section{Conceptual and procedural terms of the study}

The modern technology: is the use of modern devices such as computers, mobile phones and electronic boards to obtain knowledge and apply it in order to serve people (Ramey, 2013).

Counseling services: a group of psychological, educational and social services that provide the appropriate situation for the beneficiaries for self-understanding, and help them to solve problems and the ability to adapt with is community (Pedersen, Lonner, Draguns, Trimble, \& Rio, 2016). It is defined procedurally as: the degree obtained by the examinee on the study tool.

\section{Literature Review}

Abdul Hamid (2018) conducted a study aimed to encourage electronic counseling for the students in Saudi Arabia. The study sample consisted of 262 . The results showed that there were no statistically significant differences in the dimensions and the overall degree in terms of counselor orientation towards the use of electronic counseling according to the following variables: type, place of work and experience.

While the study of Fairburn and Patel (2017) aims to investigate the impact of digital technology on psychotherapy, based on the analysis of 12 research papers. The results showed that digital therapy is a form of cognitive behavioral therapy and is highly effective in psychotherapy. It also provides new ways to assess and follow up on psychology.

As for Al-Hayani (2016) conducted a study aimed to find out the role of the workers in caring for talented people towards electronic counseling. The study sample consisted of 100 counselors. The study showed a strong encouragement towards electronic counseling. And there were no statistically significant differences in the sample members toward electronic counseling according to the following variables: gender, years of experiences; there are differences of statistical significance in the sample members toward electronic counseling depending on the type of job in favor of the director of talented members.

Berzin, Singer and Chan (2015) conducted a study aimed to find out the social work practice through technology in the digital age. Based on the analysis of 12 research papers. The results showed that technology has led to a significant improvement in the practice of social service providers.

While Gabri, Mazzucchelli and Algeri (2015) are conducted a study aimed to understand the users of Facebook and Skype in the provision of psychology services. The study sample consisted of 45 services providers. The results showed that there are awareness and confidence in service providers.

Gale's (2015) study aimed to find out the technological developments and policies that are facing the counseling services. Based on the analysis of 12 research papers. The results showed that there is a gap between the technological advantages and policies that are facing the provision of therapeutic services. Therefore, services provide must acquire a whole new set of skills capable of providing a range of treatments. The study also noted 
that the use of technology is important for services providers and that maintaining confidentiality is also very important.

Ramey's (2013) study aimed to identify change in the provision on counseling services to families via technology and the internet. Based on analyzing 15 researches in the treatment of adolescents. The results showed that modern technology has led to positive changes in the work of services providers such as telecommunicating through social messages.

Banat, Ghaith, Albana and Baddareen (2013) examined the percentage of using electronic counseling among to counselor. The study sample consisted of 166 counselors. The results showed that the counselors use electronic counseling at an average rate. And there were no statistically significant differences in the sample members toward electronic counseling according to the following variables: gender, types of schools, and numbers of student. In the other hand the study found statistically significant differences according to educational qualification among to bachelor holders, years of experiences, for those less than 5 years of experiences.

Davis and Hastings (2013) summarized research papers on the potential uses of technology in the service of psychology. Based on analyzing 5 researches. The results showed that modern technology facilitates the job of services providers but must provide training courses for them.

Grosshandler (2012) conducted a study aimed to find out using technology by counselor in American schools. The study sample consisted of 221 counselors. The study shows that technology was not accepted by school counselors and that the ability to use technology varies from person to person and there are fears of using it.

From the point of view of the researcher this study is distinguished from previous studies because it is one of the first studies that dealt with the impact of modern technology on the provision of counseling services at the local level, in contrast to the studies that are dealt with the analysis of some researches as Fairburn and Patel (2017), Berzin el al. (2015) and Galw (2015). In the other hand there have been studies pointing to the use of technology such as Abdulhamed (2018), Al-Hayani (2016) and Grosshandler (2012). While some studies have found that the use of technology is part of psychotherapy such as Fairburn and Patel (2017) and Gale (2015).

\section{Methodology of the Study}

\subsection{Population of the Study}

The study community consist of 162 counselors who are working in the Education Directorate of Irbid of both sexes in the second semester of the academic year 2018/2017.

\subsection{Sample of the Study}

The study community consists of 125 counselors ( 71 male \& 54 female) who are working in the Education Directorate of Irbid, they were chosen by the way of mandatory. Table 1 shows the distribution of the study sample on the study variables.

Table 1. The distribution of the sample on the study variables

\begin{tabular}{llllllll}
\hline & variables & Female & $\%$ & Male & $\%$ & Total & $\%$ \\
\hline age & Less than 30 years & 19 & $15 \%$ & 26 & $21 \%$ & 45 & $36 \%$ \\
& 30-45 years & 22 & $18 \%$ & 31 & $25 \%$ & 53 & $42.4 \%$ \\
& 45 years and more & 13 & $10 \%$ & 11 & $14 \%$ & 27 & $21.6 \%$ \\
& total & 54 & $43 \%$ & 71 & $57 \%$ & 125 & 100 \\
Educational qualification & bachelor & 32 & $25 \%$ & 39 & $31 \%$ & 71 & $56.8 \%$ \\
& master & 16 & $13 \%$ & 23 & $19 \%$ & 39 & $31.2 \%$ \\
& PHD & 6 & $5 \%$ & 9 & $7 \%$ & 15 & $12 \%$ \\
& Total & 54 & $43 \%$ & 71 & $57 \%$ & 125 & $100 \%$ \\
& Less than 5 years & 18 & $14.5 \%$ & 24 & $20 \%$ & 42 & $33.6 \%$ \\
& 5-10 years & 27 & $21.5 \%$ & 33 & $26 \%$ & 60 & $48 \%$ \\
& More than 10 years & 9 & $7 \%$ & 14 & $11 \%$ & 23 & $18.4 \%$ \\
& Total & 54 & $43 \%$ & 71 & $57 \%$ & 125 & 100 \\
\hline
\end{tabular}

\subsection{Tools of the Study}

The researcher returned to literature and previous studies related to modern technology and its role in providing counseling services for people, such as Mansour's study (2014), Grosshandler (2012) and Al-Otaibi's (2011) study in order to prepare the items of the assessment tool. The assessment tools consist of 30 items as a first draft, 
distributed over 4 fields: knowledge which is consist of 10 items, infrastructure which is consist of 5 items, obstacles which is consist of 8 items and competencies which is consist of 7 items.

\subsubsection{Validity of the Tool}

The researcher verified the validity of the tool by providing the tool in its first draft, which consist of 30 items to a group of 8 arbitrators who have competence in psychological counseling, psychology and Measurement and Evaluation in Irbid National university and Yarmouk university, in order to ascertain if the assessment tool will fit all the sample, which led to amendments to some items and didn't deleted any items, where the arbitrators gathered on $85 \%$ and this ratio is reliable for conducting a study. In addition, the researcher has found the validity of the tool by applying it to a sample of 28 counseling service provider apart from the study sample and within its community then according to the correlation coefficients of all items as shown in Table 2.

Table 2. The values of correlation coefficient for tool

\begin{tabular}{|c|c|c|c|c|c|c|c|c|c|c|c|}
\hline \multirow[t]{4}{*}{ Par } & \multicolumn{2}{|c|}{ Field of knowledge } & \multirow[t]{4}{*}{ Par } & \multicolumn{2}{|c|}{ infrastructure } & \multirow[t]{4}{*}{ Par } & \multicolumn{2}{|l|}{ obstacles } & \multirow[t]{4}{*}{ Par } & \multicolumn{2}{|c|}{ competencies } \\
\hline & Correlation & Correlation & & Correlation & Correlation & & Correlation & Correlation & & Correlation & Correlation \\
\hline & Coefficient & Coefficient & & Coefficient & Coefficient & & Coefficient & Coefficient & & Coefficient & Coefficient \\
\hline & $\begin{array}{l}\text { With } \\
\text { dimension }\end{array}$ & With tool & & $\begin{array}{l}\text { With } \\
\text { dimension }\end{array}$ & With tool & & $\begin{array}{l}\text { With } \\
\text { dimension }\end{array}$ & With tool & & $\begin{array}{l}\text { With } \\
\text { dimension }\end{array}$ & With tool \\
\hline 1 & 0.56 & 0.63 & 11 & 0.69 & 0.74 & 16 & 0.48 & 0.59 & 24 & 0.72 & 0.68 \\
\hline 2 & 0.71 & 0.68 & 12 & 0.73 & 0.65 & 17 & 0.73 & 0.68 & 25 & 0.54 & 0.64 \\
\hline 3 & 0.55 & 0.61 & 13 & 0.62 & 0.57 & 18 & 0.61 & 0.68 & 26 & 0.69 & 0.61 \\
\hline 4 & 0.64 & 0.71 & 14 & 0.78 & 0.66 & 19 & 0.57 & 0.67 & 27 & 0.58 & 0.66 \\
\hline 5 & 0.61 & 0.59 & 15 & 0.61 & 0.55 & 20 & 0.61 & 0.57 & 28 & 0.77 & 0.70 \\
\hline 6 & 0.73 & 0.71 & & & & 21 & 0.79 & 0.70 & 29 & 0.60 & 0.59 \\
\hline 7 & 0.59 & 0.64 & & & & 22 & 0.66 & 0.71 & 30 & 0.71 & 0.62 \\
\hline 8 & 0.67 & 0.58 & & & & 23 & 0.70 & 0.65 & & & \\
\hline 9 & 0.74 & 0.67 & & & & & & & & & \\
\hline 10 & 0.64 & 0.57 & & & & & & & & & \\
\hline
\end{tabular}

Table 2 shows that the value of correlation coefficients ranged between $(0.74-0.55)$ for the field of knowledge, total $(0.74-0.55)$; and $(0.79-0.84)$ for obstacles, total $(0.71-0.57)$; and $(0.77-0.54)$ competencies, total $(0.70$ $0.59)$. all values are statistically significant. The researcher adopted a criterion for accepting the item that the correlation coefficient for the dimension and the tool as a whole less than (0.30) (Al-Nabhan, 2004).

\subsubsection{Stability of Assessment Tool}

The researcher verified the stability of the assessment tool in two ways: the first one by applying it to a sample of 28 counseling service providers apart from the study sample and within its community, then the internal consistency coefficient was calculated for Alpha chrnobach's dimensions. The second way: by applying it to the sample itself, it has been reapplied two weeks after its first applying. Look at Table 3.

Table 3. The coefficient of internal consistency according to the chrnobach's alpha equation for the study tool and its dimensions and stability of the repetition

\begin{tabular}{lll}
\hline Dimension & Chrnobach's Alpha & Stability of Repetition \\
\hline knowledge & 0.81 & 0.87 \\
infrastructure & 0.82 & 0.89 \\
obstacles & 0.86 & 0.88 \\
competencies & 0.83 & 0.91 \\
total & 0.83 & 0.89 \\
\hline
\end{tabular}

Table 3 shows that the value of Chrnobach's alpha ranged between $(0.86-0.81)$, total $(0.89)$, while the value of stability of repetition was ranged between $(0.91-0.87)$. The researcher believes that these values are suitable for the use of tools for the current study.

\subsubsection{Correcting Scale}

The scale is consisting of 30 items, and has been answered based on the Likert scale hierarchy as follows: 
( $1=$ strongly agree, $2=$ disagree, $3=$ neutral, $4=$ agree, $5=$ strongly agree) for three domains, with 2 items because it was responded in a positive way. As for obstacles domain, which consist of 8 items, which was responded in contradictive degree as follows: $5=$ strongly disagree, $4=$ disagree, $3=$ neutral, $2=$ agree, $1=$ strongly agree. In order to determine the level of counseling services provided by the services providers, it was adopted the level of services which is followed by (Odeh, 2010); the values were calculated based on the length of the category by using the following equitation:

$$
\text { Interval width }=\frac{\text { upper limits }(5)-\text { lower limits }(1)}{\text { The required Intervals }(3)}=\frac{4}{3}=1.33
$$

The answer was added to the end of each category as shown in Table 4.

Table 4. Levels of classification of counseling services by arithmetic mean

\begin{tabular}{ll}
\hline SMA & level \\
\hline $1-2.33$ & low \\
$2.34-366$ & middle \\
$5-3.67$ & high \\
\hline
\end{tabular}

\subsection{Procedures of the Study}

To achieve the objective of the study; the scale of the study has been prepared after verifying the indicators of its validity and stability, then the scale was distributed to counseling service providers in March of the second semester of the academic year 2017/2018, in addition to providing them by general idea about the objective and importance of the study, and the instruction of the scale were explained. And ensure that the information given will be treated with complete confidentiality and will be used for scientific purposes, then the appropriate statistical methods were used according to the (SPSS) program in order to answer the question of the study.

Recurrences, percentage, and arithmetic average of the sample responses were extracted. In order to determine the differences in the variables of the study, (Four Way ANOVA) were used in addition to (Scheffe) test for post-comparisons. To know the impact of the modern technology on the provision of counseling services, and the prev infrastructure of the modern technology; simple regression analysis was used.

\subsection{Variables of the Study}

Independent variables: (1) the modern technology, (2) Gender (male/female), (3) Age: (less than 30 years, 30 45 years, and more than 45 years), (4) Educational qualification (Bachelor, Master, BHD), (5) years of experiences (less than 5 years, 5-10 years and more than 10 years). Dependent variable: counseling services.

\section{Results of the Study}

The results of the study questions are presented below.

The First question: does modern technology contribute to provide counseling services?

To answer this question recurrences and percentage of the sample responses were extracted as what is shown in Table 5. 
Table 5. Frequency and percentage for the answers of counseling services providers the first diminution: knowledge

\begin{tabular}{|c|c|c|c|c|c|c|c|c|c|c|}
\hline & Items & & $\begin{array}{l}\text { Strongly } \\
\text { disagree }\end{array}$ & Disagree & Neutral & Agree & $\begin{array}{l}\text { Strongly } \\
\text { agree }\end{array}$ & SMA & $\begin{array}{l}\text { Standard } \\
\text { deviation }\end{array}$ & $\begin{array}{l}\text { The } \\
\text { level }\end{array}$ \\
\hline \multirow[t]{2}{*}{1} & Does the counseling & Frequency & 20 & 31 & 37 & 25 & 12 & 2.68 & 1.24 & Meddle \\
\hline & $\begin{array}{l}\text { service provider have a } \\
\text { clear vision in order to use } \\
\text { technology in providing } \\
\text { services }\end{array}$ & $\%$ & 16 & 24.8 & 2.6 & 20 & 9.6 & & & \\
\hline \multirow[t]{2}{*}{2} & Are there administrative & Frequency & 31 & 37 & 33 & 16 & 8 & 2.39 & 1.25 & Middle \\
\hline & $\begin{array}{l}\text { decisions in order to apply } \\
\text { technology for providing } \\
\text { services }\end{array}$ & $\%$ & 24.8 & 29.6 & 26.4 & 12.8 & 6.4 & & & \\
\hline \multirow[t]{2}{*}{3} & Does the administration & Frequency & 39 & 35 & 29 & 13 & 9 & 2.83 & 1.26 & Middle \\
\hline & $\begin{array}{l}\text { provide a project under } \\
\text { implementation in order to } \\
\text { apply the technology for } \\
\text { providing services }\end{array}$ & $\%$ & 31.2 & 28 & 23.2 & 10.4 & 7.2 & & & \\
\hline \multirow[t]{2}{*}{4} & Encourage the & Frequency & 41 & 36 & 24 & 14 & 10 & 3.27 & 1.18 & Middle \\
\hline & $\begin{array}{l}\text { management to spread the } \\
\text { culture of modern } \\
\text { technology in providing } \\
\text { services }\end{array}$ & $\%$ & 32.8 & 28.8 & 19.2 & 11.2 & 8 & & & \\
\hline \multirow[t]{2}{*}{5} & Counseling Service & Frequency & 40 & 38 & 26 & 12 & 9 & 3.19 & 1.26 & Middle \\
\hline & $\begin{array}{l}\text { provider have the ability to } \\
\text { implement a modern } \\
\text { technology project }\end{array}$ & $\%$ & 32 & 30.4 & 20.8 & 9.6 & 7.2 & & & \\
\hline \multirow[t]{2}{*}{6} & $\begin{array}{l}\text { do the counseling } \\
\text { providers services have the }\end{array}$ & Frequency & 24 & 10 & 13 & 37 & 41 & 2.59 & 1.23 & Middle \\
\hline & $\begin{array}{l}\text { modern technology which } \\
\text { is needed to provide } \\
\text { electronica services }\end{array}$ & $\%$ & 19.2 & 8 & 10.4 & 29.6 & 32.8 & & & \\
\hline \multirow[t]{2}{*}{7} & does technology facilitate & Frequency & 14 & 9 & 14 & 41 & 47 & 2.36 & 1.25 & Middle \\
\hline & $\begin{array}{l}\text { my work as a services } \\
\text { provider? }\end{array}$ & $\%$ & 11.2 & 7.2 & 11.2 & 32.8 & 37.6 & & & \\
\hline \multirow[t]{2}{*}{8} & is the modern technology & Frequency & 15 & 8 & 16 & 40 & 46 & 2.28 & 1.33 & Low \\
\hline & $\begin{array}{l}\text { suitable for services } \\
\text { recipient }\end{array}$ & $\%$ & 12 & 6.4 & 12.8 & 32 & 36.8 & & & \\
\hline \multirow[t]{2}{*}{9} & Does the service provider & Frequency & 13 & 7 & 14 & 42 & 49 & 2.39 & 1.42 & Middle \\
\hline & $\begin{array}{l}\text { have the essential training } \\
\text { to apply the modern } \\
\text { technology in counseling } \\
\text { work }\end{array}$ & $\%$ & 10.4 & 5.6 & 11.2 & 33.6 & 39.2 & & & \\
\hline \multirow[t]{4}{*}{10} & Does the service provider & Frequency & 10 & 9 & 17 & 41 & 48 & 2.58 & 1.23 & Middle \\
\hline & $\begin{array}{l}\text { have the flexibility to deal } \\
\text { with rapid changes in } \\
\text { modern technology }\end{array}$ & $\%$ & 8 & 7.2 & 13.6 & 32.8 & 38.4 & & & \\
\hline & Total & Frequency & 247 & 220 & 223 & 281 & 279 & 2.65 & 1.23 & Middle \\
\hline & & $\%$ & 19.8 & 17.6 & 17.8 & 22.5 & 22.3 & & & \\
\hline
\end{tabular}

The second dimension: infrastructure

\begin{tabular}{|c|c|c|c|c|c|c|c|c|c|c|}
\hline 11 & $\begin{array}{l}\text { The availability of } \\
\text { equipment for applying the } \\
\text { electronic services }\end{array}$ & $\begin{array}{l}\text { Frequency } \\
\%\end{array}$ & $\begin{array}{l}26 \\
20.8\end{array}$ & $\begin{array}{l}21 \\
16.8\end{array}$ & $\begin{array}{l}17 \\
13.6\end{array}$ & $\begin{array}{l}29 \\
23.2\end{array}$ & $\begin{array}{l}32 \\
25.6\end{array}$ & 3.38 & 1.36 & Middle \\
\hline 12 & $\begin{array}{l}\text { The available of internet } \\
\text { service }\end{array}$ & $\begin{array}{l}\text { Frequency } \\
\%\end{array}$ & $\begin{array}{l}19 \\
15.2\end{array}$ & $\begin{array}{l}17 \\
13.6\end{array}$ & $\begin{array}{l}23 \\
18.4\end{array}$ & $\begin{array}{l}32 \\
25.6\end{array}$ & $\begin{array}{l}34 \\
27.2\end{array}$ & 2.41 & 1.31 & Middle \\
\hline 13 & $\begin{array}{l}\text { Provides continuous } \\
\text { internet connectivity }\end{array}$ & $\begin{array}{l}\text { Frequency } \\
\%\end{array}$ & $\begin{array}{l}37 \\
29.6\end{array}$ & $\begin{array}{l}26 \\
20.8\end{array}$ & $\begin{array}{l}18 \\
14.4\end{array}$ & $\begin{array}{l}21 \\
16.8\end{array}$ & $\begin{array}{l}23 \\
18.4\end{array}$ & 2.32 & 1.25 & Low \\
\hline 14 & $\begin{array}{l}\text { Privacy is available for } \\
\text { service providers and } \\
\text { recipient }\end{array}$ & $\begin{array}{l}\text { Frequency } \\
\%\end{array}$ & $\begin{array}{l}47 \\
37.6\end{array}$ & $\begin{array}{l}36 \\
28.8\end{array}$ & $\begin{array}{l}9 \\
7.2\end{array}$ & $\begin{array}{l}18 \\
14.4\end{array}$ & $\begin{array}{l}15 \\
12\end{array}$ & 3.08 & 13.4 & Middle \\
\hline 15 & $\begin{array}{l}\text { Provide a continuous } \\
\text { technical support for the } \\
\text { counseling services } \\
\text { provider }\end{array}$ & $\begin{array}{l}\text { Frequency } \\
\%\end{array}$ & $\begin{array}{l}39 \\
31.2\end{array}$ & $\begin{array}{l}28 \\
22.4\end{array}$ & $\begin{array}{l}16 \\
12.8\end{array}$ & $\begin{array}{l}23 \\
18.4\end{array}$ & $\begin{array}{l}19 \\
15.2\end{array}$ & 2.69 & 13.7 & Middle \\
\hline & Total & $\begin{array}{l}\text { Frequency } \\
\%\end{array}$ & $\begin{array}{l}168 \\
26.8\end{array}$ & $\begin{array}{l}128 \\
20.5\end{array}$ & $\begin{array}{l}83 \\
13.3\end{array}$ & $\begin{array}{l}123 \\
19.7\end{array}$ & $\begin{array}{l}123 \\
19.7\end{array}$ & 2.78 & 1.37 & Middle \\
\hline
\end{tabular}


The third dimension: obstacles

\begin{tabular}{|c|c|c|c|c|c|c|c|c|c|c|}
\hline \multirow[t]{2}{*}{16} & \multirow[t]{2}{*}{ High cost } & Frequency & 26 & 20 & 12 & 37 & 30 & \multirow[t]{2}{*}{3.32} & \multirow[t]{2}{*}{1.42} & \multirow[t]{2}{*}{ Middle } \\
\hline & & $\%$ & 20.8 & 16 & 9.6 & 29.6 & 24 & & & \\
\hline \multirow[t]{2}{*}{17} & \multirow{2}{*}{$\begin{array}{l}\text { Lack of specialists for } \\
\text { technical maintenance }\end{array}$} & Frequency & 23 & 21 & 19 & 34 & 28 & \multirow[t]{2}{*}{3.26} & \multirow[t]{2}{*}{1.28} & \multirow[t]{2}{*}{ Middle } \\
\hline & & $\%$ & 18.4 & 16.8 & 15.2 & 27.2 & 22.4 & & & \\
\hline \multirow[t]{2}{*}{18} & \multirow[t]{2}{*}{ Weak infrastructure } & Frequency & 16 & 17 & 13 & 42 & 37 & \multirow[t]{2}{*}{2.41} & \multirow[t]{2}{*}{1.37} & \multirow[t]{2}{*}{ Middle } \\
\hline & & $\%$ & 12.8 & 13.6 & 10.4 & 33.6 & 29.6 & & & \\
\hline \multirow[t]{2}{*}{19} & \multirow{2}{*}{$\begin{array}{l}\text { Poor qualification of } \\
\text { services providers with the } \\
\text { required skills }\end{array}$} & Frequency & 14 & 12 & 11 & 48 & 40 & \multirow[t]{2}{*}{2.85} & \multirow[t]{2}{*}{1.25} & \multirow[t]{2}{*}{ Middle } \\
\hline & & $\%$ & 11.2 & 9.6 & 8.8 & 38.4 & 32 & & & \\
\hline \multirow[t]{2}{*}{20} & \multirow{2}{*}{$\begin{array}{l}\text { Using of computer and } \\
\text { internet in the counseling } \\
\text { services }\end{array}$} & Frequency & 29 & 28 & 9 & 28 & 31 & \multirow[t]{2}{*}{2.67} & \multirow[t]{2}{*}{1.20} & \multirow[t]{2}{*}{ Middle } \\
\hline & & $\%$ & 23.2 & 22.4 & 7.2 & 22.4 & 24.8 & & & \\
\hline \multirow[t]{2}{*}{21} & \multirow{2}{*}{$\begin{array}{l}\text { The technical problems } \\
\text { that result from the } \\
\text { interruption of } \\
\text { communication }\end{array}$} & Frequency & 19 & 23 & 14 & 36 & 33 & \multirow[t]{2}{*}{2.66} & \multirow[t]{2}{*}{1.23} & \multirow[t]{2}{*}{ Middle } \\
\hline & & $\%$ & 15.2 & 18.4 & 11.2 & 28.8 & 26.4 & & & \\
\hline \multirow[t]{2}{*}{22} & \multirow{2}{*}{$\begin{array}{l}\text { Fear of illegal break-ins } \\
\text { and disclosure of } \\
\text { information related to the } \\
\text { recipient }\end{array}$} & Frequency & 11 & 10 & 19 & 45 & 40 & \multirow[t]{2}{*}{2.69} & \multirow[t]{2}{*}{1.24} & \multirow[t]{2}{*}{ Middle } \\
\hline & & $\%$ & 8.8 & 8 & 15.2 & 36 & 32 & & & \\
\hline 23 & Reject change among & frequency & 13 & 16 & 22 & 39 & 35 & 2.71 & 1.27 & Middle \\
\hline & $\begin{array}{l}\text { services provider towards } \\
\text { the use of technology }\end{array}$ & $\%$ & 10.4 & 12.8 & 17.6 & 31.2 & 28 & & & \\
\hline & Total & Frequency & 108 & 98 & 64 & 189 & 166 & 2.82 & 1.20 & Middle \\
\hline & & $\%$ & 17.3 & 15.7 & 10.2 & 30.2 & 26.6 & & & \\
\hline
\end{tabular}

The fourth dimension: competences

\begin{tabular}{|c|c|c|c|c|c|c|c|c|c|c|}
\hline 24 & $\begin{array}{l}\text { Competence use of } \\
\text { communication programs } \\
\text { and means of modern } \\
\text { technology }\end{array}$ & $\begin{array}{l}\text { Frequency } \\
\%\end{array}$ & $\begin{array}{l}27 \\
21.6\end{array}$ & $\begin{array}{l}24 \\
19.2\end{array}$ & $\begin{array}{l}9 \\
7.2\end{array}$ & $\begin{array}{l}34 \\
27.2\end{array}$ & $\begin{array}{l}31 \\
24.8\end{array}$ & 2.48 & 1.25 & Middle \\
\hline 25 & $\begin{array}{l}\text { Competence of dealing } \\
\text { with technology }\end{array}$ & $\begin{array}{l}\text { Frequency } \\
\%\end{array}$ & $\begin{array}{l}29 \\
23.2\end{array}$ & $\begin{array}{l}27 \\
21.6\end{array}$ & $\begin{array}{l}7 \\
5.6\end{array}$ & $\begin{array}{l}32 \\
25.6\end{array}$ & $\begin{array}{l}30 \\
24\end{array}$ & 1.24 & 2.27 & Low \\
\hline 26 & $\begin{array}{l}\text { Competencies related to } \\
\text { management a counseling } \\
\text { work }\end{array}$ & $\begin{array}{l}\text { Frequency } \\
\%\end{array}$ & $\begin{array}{l}18 \\
14.4\end{array}$ & $\begin{array}{l}19 \\
15.2\end{array}$ & $\begin{array}{l}11 \\
8.8\end{array}$ & $\begin{array}{l}39 \\
31.2\end{array}$ & $\begin{array}{l}38 \\
30.4\end{array}$ & 1.19 & 2.99 & Middle \\
\hline 27 & $\begin{array}{l}\text { Competencies related to } \\
\text { computer use }\end{array}$ & $\begin{array}{l}\text { Frequency } \\
\%\end{array}$ & $\begin{array}{l}25 \\
20\end{array}$ & $\begin{array}{l}22 \\
17.6\end{array}$ & $\begin{array}{l}13 \\
10.4\end{array}$ & $\begin{array}{l}32 \\
25.6\end{array}$ & $\begin{array}{l}33 \\
26.4\end{array}$ & 1.16 & 2.77 & Middle \\
\hline 28 & $\begin{array}{l}\text { Maintenance related to } \\
\text { internet use }\end{array}$ & $\begin{array}{l}\text { Frequency } \\
\%\end{array}$ & $\begin{array}{l}14 \\
11.2\end{array}$ & $\begin{array}{l}12 \\
9.6\end{array}$ & $\begin{array}{l}11 \\
8.8\end{array}$ & $\begin{array}{l}46 \\
36.8\end{array}$ & $\begin{array}{l}42 \\
33.6\end{array}$ & 1.18 & 2.62 & Middle \\
\hline 29 & $\begin{array}{l}\text { Maintenance of the } \\
\text { requiring equipment's }\end{array}$ & $\begin{array}{l}\text { Frequency } \\
\%\end{array}$ & $\begin{array}{l}36 \\
28.8\end{array}$ & $\begin{array}{l}32 \\
25.6\end{array}$ & $\begin{array}{l}16 \\
12.8\end{array}$ & $\begin{array}{l}23 \\
18.4\end{array}$ & $\begin{array}{l}18 \\
14.4\end{array}$ & & & \\
\hline 30 & $\begin{array}{l}\text { Competencies related to } \\
\text { software and } \\
\text { communication programs }\end{array}$ & $\begin{array}{l}\text { Frequency } \\
\%\end{array}$ & $\begin{array}{l}24 \\
19.2\end{array}$ & $\begin{array}{l}21 \\
16.8\end{array}$ & $\begin{array}{l}12 \\
9.6\end{array}$ & $\begin{array}{l}31 \\
24.8\end{array}$ & $\begin{array}{l}37 \\
29.6\end{array}$ & & & \\
\hline & Total & $\begin{array}{l}\text { Frequency } \\
\%\end{array}$ & $\begin{array}{l}173 \\
19.8\end{array}$ & $\begin{array}{l}157 \\
17.9\end{array}$ & $\begin{array}{l}79 \\
9\end{array}$ & $\begin{array}{l}237 \\
27.1\end{array}$ & $\begin{array}{l}229 \\
26.2\end{array}$ & 2.53 & 1.26 & Middle \\
\hline & The tool as a whole & & & & & & & 2.70 & 1.27 & Middle \\
\hline
\end{tabular}

Table 5 indicates that the sample member use technology in providing counseling services at middle level, where arithmetic means was 2.70 and standard deviation 1.27. While competences come at the first place with arithmetic means was 2.82 and standard deviation 1.20. As for the infrastructure dimension which comes at the second place with arithmetic means 2.65 and standard deviation 1.23 . Finally, the competence arithmetic means 2.53 and standard deviation 1.26. All of them were of average level.

The second question: are there significant statistical differences for the modern technology on the provision of counseling services according to the following variables: gender, age, qualifications and years of experiences. 
Table 6 shows the results of quadratic variance analysis to determine the effect of gender, age, qualification and years of experiences.

Table 6. The results of quadratic variance analysis to determine the impact of gender, age, qualification and years of experiences

\begin{tabular}{llllll}
\hline Source of variance & Freedom significance level & Average squares & Total squares & "F" & Level of significance \\
\hline Gender & 37.557 & 1 & 37.557 & 0.98 & 0.322 \\
Age & 37.560 & 2 & 37.560 & 7.145 & $* 0.000$ \\
qualification & 4.334 & 2 & 4.334 & 1.210 & 0.621 \\
Years of experiences & 6.093 & 2 & 6.093 & 5.843 & $* 0.000$ \\
The error & 5.503 & 118 & 5.503 & & \\
total & 782.314 & 125 & & & \\
\hline
\end{tabular}

Note. *statistical significance at the level $(0.05 \geq \alpha)$.

Table 6 shows that there are no statistically significant differences at the level $(0.05 \geq \alpha)$ according to the following variables: gender, age, qualifications and years of experiences but there are statistically significant differences at the level $(0.05 \geq \alpha)$ according to: age and years of experiences. In order to determine the statistical significance of these differences in age, the Scheffe test was used for the post comparisons as shown in Table 7.

Table 7. The results of Scheffe test for the post comparisons according to the age

\begin{tabular}{llllll}
\hline & age & & Less than 30 years & $30-45$ years & More than 45 years \\
\hline tool & & average & 4.12 & 3.89 & 3.53 \\
Modern technology & Less than 30 years & 4.12 & 4.12 & 0.11 & $* 0.33$ \\
& 30-45 years & 3.89 & & & $* 0.28$ \\
& More than 45 years & 3.53 & & & \\
\hline
\end{tabular}

Note. *statistical significance at the level $(0.05 \geq \alpha)$.

Table 7 shows that there are statistically significant differences at the level $(0.05 \geq \alpha)$ according to the age variable for (less than 30 years, $30-45$ years). In order to determine the statistical significance of these difference in the years of experiences, the Scheffe test was used for the post comparisons as shown in Table 8.

Table 8. The results of Scheffe test for the post comparisons according to the years of experiences

\begin{tabular}{llllll}
\hline & Years of experiences & & Less than 5 years & $5-10$ years & More than 10 years \\
\hline tool & & average & 4.07 & 3.75 & 3.98 \\
Modern technology & Less than 5years & 4.07 & & $* 0.29$ & 0.09 \\
& 5-10 years & 3.75 & & & 0.12 \\
& More than 10 years & 3.98 & & & \\
\hline
\end{tabular}

Note. *statistical significance at the level $(0.05 \geq \alpha)$.

Table 8 shows that there are statistically significant differences at the level $(0.05 \geq \alpha)$ according to the years of experiences variable for (less than 5 years) (5-10 years).

Third question: is there a relation with statistically significant at the level $(0.05 \geq \alpha)$ for the impact of the modern technology on the provision of counseling services? In order to answer this question, a simple regression analysis was performed to detect the impact of modern technology on the provision of counseling services, as shown in Table 9.

Table 9. The results of a simple regression analysis to detect the impact of modern technology on the provision of counseling services

Note. ${ }^{*} \mathrm{p}<0.0001$.

\begin{tabular}{lllll}
\hline B value & $\mathrm{R}$ Multiple correlation & $\mathrm{R}^{2}$ variance & $\mathrm{F}$ & Statistical analysis \\
\hline 0.28 & 0.55 & 0.30 & 139.05 & $0.000^{*}$ \\
\hline
\end{tabular}


The results of the simple regression analysis show that there is statistically significant at the level $(0.05 \geq \alpha)$ for the impact of the modern technology on the provision of counseling services, where it is value was $(\mathrm{F}=139.05)$ and the statistically significant level $(0.000)$, what enhances this result is the correlation coefficient between the two variables $(0.55)$, which is accepted value.

Fourth question: is there a relation with statistically significant at the level $(0.05 \geq \alpha)$ for the impact of infrastructure of the modern technology on the provision of counseling services? In order to answer this question, a simple regression analysis was performed to detect the impact of modern technology on the provision of counseling services, as shown in Table 10.

Table 10. The results of a simple regression analysis to detect the impact of infrastructure of the modern technology on the provision of counseling services

\begin{tabular}{lllll}
\hline B value & R Multiple correlation & $\mathrm{R}^{2}$ variance & $\mathrm{F}$ & Statistical analysis \\
\hline 0.34 & 0.51 & 0.26 & 118.21 & $0.000^{*}$ \\
\hline
\end{tabular}

Note. ${ }^{*} \mathrm{p}<0.0001$

The results of the simple regression analysis show that there is statistically significant for providing infrastructure of the modern technology on the provision of counseling services is less than $(0.05 \geq \alpha)$, where the value was $(\mathrm{F}=118.21)$ and the statistically significant level $(0.000)$, what enhances this result is the correlation coefficient between the two variables $(0.51)$, which is accepted value.

The results of the first question shown that the samples of the study was at an average level in using modern technology on the provision of counseling services, while the obstacles dimension was at the first place, that is because the majority of counselors are consider these problem are increasing the burden of counseling work, for example, to stop connecting to the internet suddenly makes it difficult to open e-mail, browse slowly, in addition to problems in downloading files, videos and pictures from the internet. As for the high cost which is come at the last stage of the obstacles. The researcher found that the counselor in the schools find it difficult to provide the technological counseling services environment inside the counseling rooms by the require preparation of counseling programs and safe environment for data protection and storage. In addition, the researcher finds that it is necessary to establish suitable infrastructure in schools and rehabilitate them by holding training courses.

As for the knowledge dimension, which came an average level because of the inefficiency of some counselors, the lack of awareness of using technology and internet, and lack of interest in technology and its role in the development of counseling work in schools. While the researcher attributed the access of infrastructure to the average degree due to absence of using the modern technology and poor use by the services providers, despite the availability in their schools in addition to the lack of system or formal programs that help providers to use it and save the data for the counselor. The other reason, according to the researcher, is that some users do not trust this technology, in addition to the rapid developments that leads to the inability to cope with them.

As for the competences dimension, which is came in the third stage with the average level, according to the researcher because it is one of the most important competencies that must be provides by the counselor who are dealing with distance communication. The knowledge dimension also came at the same level of competences; because that the university qualification does not provide specialized courses in this domain. This study coincides with the study of Berzin et al. (2015) and Davies and Hastings (2013), which indicates the need for training service providers.

The results of the second question show that there are differences of statistical significance for using modern technology on the provision of counseling services according to gender and years of experiences. While there are no statistical differences according to gender and educational qualification. The reason for the absence of the differences of statistical significance for gender because of using technology is not related to specific type of gender. The results of this study are consistent with the study of Abdul Hamid (2018), Alhaiyani (2016) and Banat (2013), all of them indicate that there are no statistically significant differences in the provision of services according to gender.

Also, the reasons for the absence of the differences of statistical significance for the educational qualification because all members of the sample have the same level of skills in using modern technology, regardless of their educational qualifications, but this study differs with Banat study (2013) which indicates a statistically significant differences in the educational qualification according to bachelor's holder. 
The reason for superiority of the counselor who are (less than 30 years, 30-45years) more than who are (more than 45) because of the different stages of age, so they will have a significant impact on their abilities and skills.

There are differences in using the modern technology on the provision of counseling services among years of experiences for less than 5 years, because they have a positive view of technology, in addition to the fact that they have used modern technology more because they have experienced this techno in their daily life and academic life, not like the more experienced counselor, who have received face-to-face counseling, in addition to the lack of modern technology developments. This study coincides with the study of Banat (2013), which found that there are differences of statistically significant among the years of experiences for the less than 5 years. But this study differs with Abdul Hameed study (2018) and Alhaiany (2016) which indicates that there are no a statistically significant differences according to the year of experiences.

As for the results of questions three and four it found that there are differences of statistically significant for the impact of modern technology in the provision of counseling services according to the infrastructure variable because the application of technology, communications and infrastructure are essential to achieve the objectives of the counseling process. In addition to improve the quality of counseling work, and the human technological capabilities can increase the provision of the essential services for many recipients.

The researcher also believes that the counselors can obtain various reports, whether behavioral or psychological, through websites and electronic programs, where these programs are characterized by flexibility and ease of modifications. This study coincides with the study of Fairburn and Patel (2017), which indicated that modern technology provides new ways to assess the state psychiatric patients. And Berzin et al. (2015) which showed a significant improvement on social service providers. Ramey (2013) and Davies and Hastings (2013) summarized that the modern technology has led to a positive change which facilitated to the process of remote counseling services providers through social media.

\section{Recommendations, Implications, and Limitations}

Based on the results, the researchers recommend the following:

1) Expand the role of the counseling provider, in order to provide counseling services using modern technology.

2) Cognitive preparation and training in technological skills for the counselor on the provision of counseling services by using technology.

3) Rehabilitation of the old age counselor and old graduates in the technological side

4) Provide the different competencies of the counselor in the use of modern technology in counseling services.

However, the main limitations of this study are the following:

Temporal limits: the researcher applied the study in the second semester of the academic year 2018/2017.

Spatial limits: is has been applied in the education Directorate of Irbid, in the northern city of Irbid.

Human boundaries: The sample included only the counselor who is working in the education Directorate of Irbid.

Objective boundaries: The possibility of generalized study results is determined by the study tool, its Symmetric characteristics, and the methodology used to answer.

\section{References}

Abdul Hamid, A. (2018). Predicting the trends toward electronic counseling in the light of the variables of professional life and professional compatibility among to Saudi counselor students. Journal of Faculty of Education in Asset, 34(3), 301-373.

Al-Qawasmi, A. (2017). Interactive academic counseling: technological dimensions proposed to ALmajmaa' University.

Allahianui, M. (2016). E-counseling in the sample worker on providing the talented people in the general Administration of Education in Jeddah: Comparative study. Journal of Special Education and Rehabilitation, 3(10), 320-355.

Alnabhan, M. (2004). The Basics of Measurement in Behavioral Sciences. Amman dar alshouroq for publishing and distribution.

Aronson, I., Plass, J., \& Bania T. (2012). Optimizing educational video through comparative trials in clinical environments. Educational Technology Researcher and Development, 60(3), 469-482. https://doi.org/10.1007/s11423-011-9231-4 
Banat, S., Ghaith, S. A., Mohamed, B., \& Ghaleb. (2013). Using of computer technicians in the Jordanian government schools by counselor. The Educational Journal, 109(1), 75-126.

Berzin, S., Singer, J., \& Chan, C. (2015). Practice innovation through technology in the digital age: A grand challenge for social work. Grand Challenges for social work imitative, Working paper No. 12, American of social work and social welfare.

Bickel, W., Marsch, L., \& Budney, A. (2013). Technology-delivered treatments for substance use disordeers: Current status and future directions. In P. M. Miller (Ed.), Interventions for Addiction: Comprehensive addictive Behaviors and Disorders (vol. 3, cha. 29, pp. 275-286). Academic press.

Campbell, A., Nunes, E., Matthews, A., Stitzer, M., Miele. G., \& Polsky, D. (2014). Internet-delivered treatment for substance abuse: a multisite randomized controlled trial. Am J Psychiatry, 171(6), 683-690. https://doi.org/10.1176/appi.ajp.2014.13081055

Davies, S., \& Hastings, R. (2013). Computer technology in clinical psychology services for people with mental retardation: A review. Education and Training in Development Disabilities, 38(38), 341-352.

Fairburn, C., \& Patel, V. (2017). The impact of digital technology on psychological treatments and their dissemination. Behavior Research and Therapy, 88(2), 19-25. https://doi.org/10.1016/j.brat.2016.08.012

Gabri, S., Mazzucchelli, L., \& Algeri, D. (2015). The request for psychological help in the digital age: offering counseling through chat and video.

Gale, B. (2015). Technological and delivery of psychological services.

Grosshandler, N. (2012). Exploring technology usage by school counselors: A mixed methods study. Ph. D thesis, university of Nebraska, Lincoln, USA.

Maheu, M., M. J., \& Puier, M. (2013). Optimizing the use of technology in psychology with best practice principles.

Mansour, T., \& Mansour, H. (2014). The impact of using communication technology on public relations functions in the Jordanian health sector. Studies of Human and Social Relation, 41(2), 801-820.

Odeh, A. (2010). Measurement and evaluation in teaching process. Irbid: Dar AL Amal for publishing and distribution.

Otaibi, A. (2010). The impact of using technology on the performance of human resources: field study on the Australian international Academy. Abu Dhabi, United Arab Emirates.

Pedersen, P., Lonner, W., Draguns, J., Trimble, J., \& Rio, M. (2016). Counseling Across Cultures. Califorina: SAGE publishing. https://doi.org/10.4135/9781483398921

Ramey, K. (2013). What is technology-meaning of technology and its use? Retrieved from http://www.useoftechnology.com/what-is-technology/

Ratliff, K., Ebbs, S., \& Isom, M. (2012). Influence of technology in school counseling. Retrieved from https://edutrendaonline.com/2012/12/18/influence-of-technology-in-school-counseling/

Takroni, N. (2012). Contribution of the student counselor in the development of the personality of the student of the primary level of the Islamic education. UN published MA thesis, umm Al-Qura University, Makkah, Saudi Arabia.

Zur, O. (2012). Telepsychology or Elemental Health in the Digital Age: The Future is Here. California Psychologist, 45(1), 13-15.

Zur, O., \& Zur, A. (2016). On digital immigrants and digital natives: How the digital divide affects affects families, educational institutions, and the workplace. Retrieved from http://www.zurinstitute.com/digital_divide.html

\section{Copyrights}

Copyright for this article is retained by the author, with first publication rights granted to the journal.

This is an open-access article distributed under the terms and conditions of the Creative Commons Attribution license (http://creativecommons.org/licenses/by/4.0/). 